\title{
Preparation of Organometallic Hydroxides and their Reactions with Lanthanide Compounds
}

\begin{tabular}{|c|c|}
\hline Journal: & Zeitschrift für Anorganische und Allgemeine Chemie \\
\hline Manuscript ID: & zaac.201000074.R1 \\
\hline Wiley - Manuscript type: & Research Report \\
\hline $\begin{array}{r}\text { Date Submitted by the } \\
\text { Author: }\end{array}$ & 21-Apr-2010 \\
\hline Complete List of Authors: & Roesky, Herbert; Universitaet Goettingen, Chemistry \\
\hline Keywords: & $\begin{array}{l}\text { Organometallic Hydroxides , Organometallic Oxides, } \\
\text { Lanthanides }\end{array}$ \\
\hline
\end{tabular}

\section{今 scholaroNE" \\ Manuscript Central}




\title{
Research Report
}

\section{Preparation of Organometallic Hydroxides and their Reactions with Lanthanide Compounds}

\author{
Herbert W. Roesky [a]
}

\begin{abstract}
Keywords
Organometallic Hydroxides; Organometallic Oxides; Lanthanides; Aluminum; Gallium; Germanium.
\end{abstract}

\begin{abstract}
The preparation of soluble organometallic hydroxides is a key step in the preparation of organometallic oxides containing the heterobimetallic M-O-M' unit. Compounds of composition $\mathrm{LMOH}$ where $\mathrm{M}$ is a Main Group metal ( $\mathrm{Ca}, \mathrm{Sr}, \mathrm{Al}, \mathrm{Ga}$, $\mathrm{Ge}, \mathrm{Sn})$ and transition metal $(\mathrm{Zr}, \mathrm{Hf})$ are summarized. The reactions of $\mathrm{Cp}_{3} \mathrm{Ln}(\mathrm{Ln}=$ $\mathrm{Yb}, \mathrm{Dy}, \mathrm{Er}, \mathrm{Sm})$ with several hydroxides to yield compounds with the skeletons $\mathrm{M}(\mu-$ $\mathrm{O}) \mathrm{Ln}$ and $\mathrm{M}(\mu-\mathrm{OH}) \mathrm{Ln}$ are reported. The application of the latter compounds in $\epsilon_{-}$ caprolactone polymerization is discussed. An unforeseen formation of a chlorinecentered cluster of composition $\left[\left(\mathrm{Me}_{3} \mathrm{Si}\right)_{2} \mathrm{NC}(\mathrm{NCy})_{2} \mathrm{SmCl}_{2}\right]_{5}(\mathrm{THF})_{2}$ is reported.
\end{abstract}

\section{Introduction}

Heterobi- and heteropoly-metallic compounds are of great interest ranging from advanced materials to efficient catalysts. The compounds with different metals have often modified the properties of the individual metal atoms, a feature that is difficult to achieve otherwise. For example, two metal atoms with a given property when combined together in a compound can apply synergetically to an entirely new behavior. For that reason the combination of two different metals in one compound in a desired proximity is very important. Two different metals are believed to be better than one in catalysis because of the cooperative effect between two metal centers. In addition, these systems might function as both catalyst and cocatalyst in the same complex [1-3]. Our approach in this field to arrange two different metals in close proximity to each other was the generation of compounds containing an oxygen bridge between two different metals of composition M-O-M'. An early experiment using alkoxides of different metals such as $\mathrm{Ti}(\mathrm{OR})_{4}$ and $\mathrm{Zr}(\mathrm{OR})_{4}$ to

a) Universität Göttingen, Institut für Anorganische Chemie, Tammannstrasse 4, 37077 Göttingen. Tel: 0551 393001; Fax: 0551 393373; e-mail: hroesky@gwdg.de 
prepare heterobimetallic $\mathrm{Ti}-\mathrm{O}-\mathrm{Zr}$ compounds failed, due to the different rates of hydrolysis of these compounds in the presence of water. In this case it leads to the deposition of anatase rather than to a compound with a $\mathrm{Ti}-\mathrm{O}-\mathrm{Zr}$ bond. The synthetic strategy which we developed is the preparation of well-defined organometallic hydroxides and their reactions with various metallic substrates [4].

\section{Results and Discussion}

\section{Organometallic Hydroxides}

a) Organometallic hydroxides of Group 13

Organometallic hydroxides are a class of compounds which have been prepared mainly by serendipity especially while looking for something else entirely unrelated. Therefore organometallic hydroxides are considered by chemists as compounds which have been prepared under conditions not carefully accomplished, with the result that the chemistry of organometallic hydroxides has been neglected $[5,6]$. In contrast to this historic development we became interested in preparing organometallic hydroxides as precursors to assemble heterobimetallic oxides with the $\mathrm{M}-\mathrm{O}-\mathrm{M}$ ' arrangement. The synthesis of an aluminum hydroxide and the corresponding gallium congener supported by a $\beta$-diketiminate ligand is shown in Scheme $1[7,8]$. The sterically demanding $\beta$-dikiminate ligand turned out to be the ligand of choice in this synthesis, as it not only provides the delicate electronic balance and electronic relief to the Lewis acidic metal center on the account of its electron rich nitrogen atoms, but the bulky 2,6-diisopropyl phenyl substituents on nitrogen atoms render also the necessary steric protection. The overall result is the prevention of self condensation, and thus the formation of oligomeric polynuclear non-soluble cage compounds.

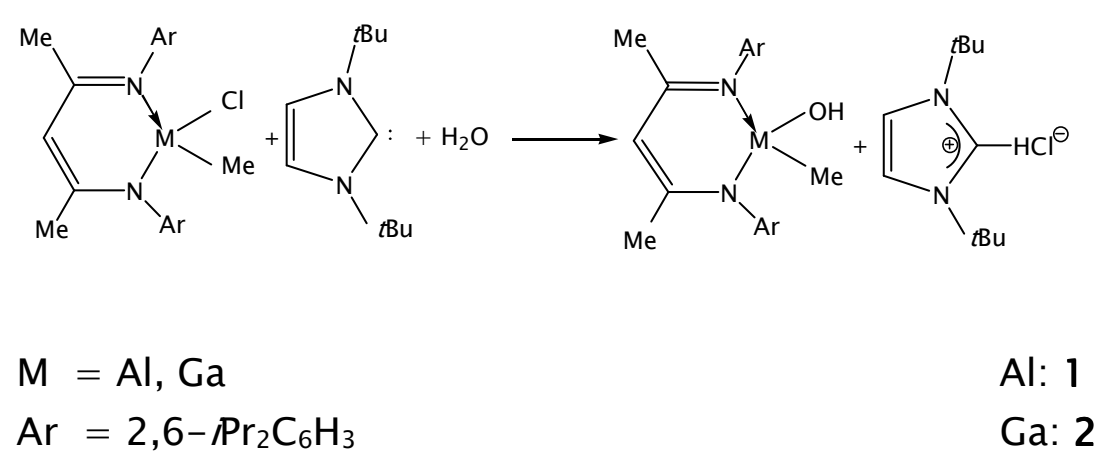

Scheme 1: Preparation of monohydroxo complexes of aluminum and gallium 
The structure of $\mathrm{LAI}(\mathrm{Me}) \mathrm{OH})(1)\left(\mathrm{L}=\mathrm{CH}(\mathrm{NArCMe})_{2}, \mathrm{Ar}=2,6-\mathrm{Pr}_{2} \mathrm{C}_{6} \mathrm{H}_{3}\right)$ is shown in Figure 1 [7].

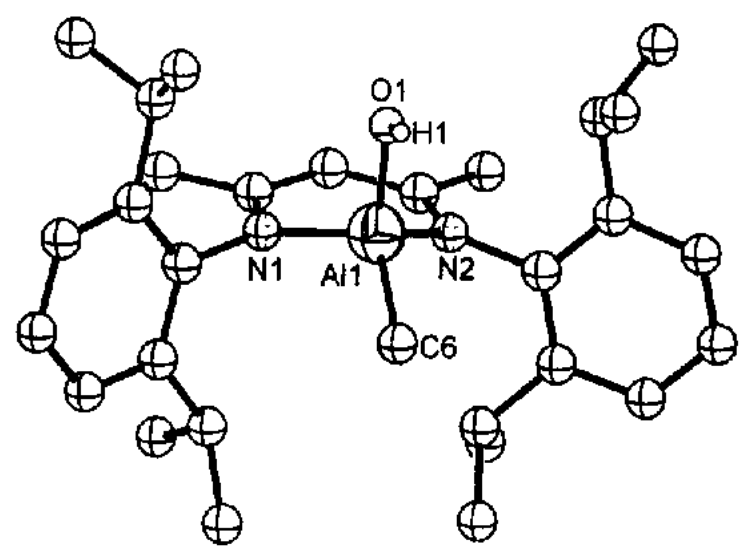

Figure 1: Perspective view of the $\beta$-diketiminate methylaluminum hydroxide (1)

The aluminum monohydroxide $\mathrm{LAl}(\mathrm{Me}) \mathrm{OH}(1)$ is very stable and did not eliminate methane to yield LAIO, even when heated above its melting point $\left(192^{\circ} \mathrm{C}\right)$.

In the course of this project we prepared a number of derivatives of $\mathrm{LAl}(\mathrm{Me}) \mathrm{OH}$ (1) by replacing the methyl group by other substituents to investigate the properties of these aluminum hydroxides on a broader scale. In addition we used differently substituted $\beta$-diketiminates (Scheme 2) for the preparation of the aluminum precursors [9]. 


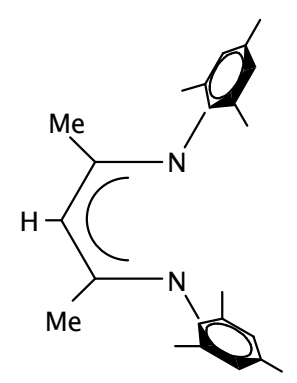

$\mathrm{L}=\mathrm{L}^{1}$

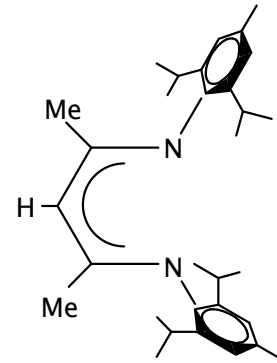

$L=L^{2}$

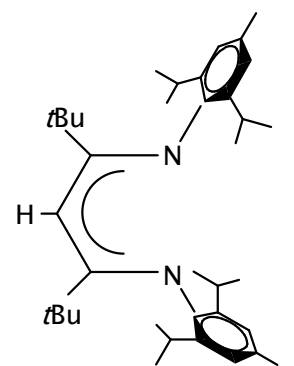

$L=L^{3}$

Scheme 2: Differently substituted ligand L

In general, LH was converted by $n \mathrm{BuLi}$ to the $\mathrm{LLi}$ and then treated with $\mathrm{EtAlCl}_{2}$ to yield $\mathrm{LAI}(\mathrm{Et}) \mathrm{Cl}$. This procedure followed the preparation of $\mathrm{LAI}(\mathrm{Me}) \mathrm{Cl}$. However, for the introduction of the $\mathrm{C}_{6} \mathrm{H}_{5}$, OEt and $\mathrm{OSiMe}_{3}$ groups we prepared first $\mathrm{LAICl}_{2}$ and treated this with the corresponding lithium salts.

The hydrolysis of LAIRCI in the presence of 1,3-diisopropyl-4,5-dimethylimidazol2 -ylidene $(: C)$ as a $\mathrm{HCl}$ scavenger resulted in the formation of $\mathrm{LAI}(\mathrm{R}) \mathrm{OH}$ (Scheme 3 ).<smiles>[R][AlH2]Cl</smiles><smiles>CC#CCO</smiles><smiles>[R][AlH2]O</smiles>

$3-8$

$$
\begin{array}{lll}
\mathrm{L}=\mathrm{L}^{1}, & \mathrm{R}=\mathrm{Et} & \mathbf{3} \\
\mathrm{L}=\mathrm{L}^{2}, & \mathrm{R}=\mathrm{Et} & \mathbf{4} \\
\mathrm{L}=\mathrm{L}^{1}, & \mathrm{R}=\mathrm{Ph} & \mathbf{5} \\
\mathrm{L}=\mathrm{L}^{2} . & \mathrm{R}=\mathrm{Ph} & \mathbf{6} \\
\mathrm{L}=\mathrm{L}^{2}, & \mathrm{R}=\mathrm{OEt}^{2} & \mathbf{7} \\
\mathrm{L}=\mathrm{L}^{2} & \mathrm{R}=\text { OSiMe }_{3} & \mathbf{8}
\end{array}
$$

Scheme 3: Preparation of compounds of composition LAl(R)OH 
Compounds $\mathbf{3}$ - $\mathbf{8}$ were formed in low yield compared to $\mathrm{LAl}(\mathrm{Me}) \mathrm{OH}$ (1). Moreover, they turned out to be less stable than 1 so that reactions with $\mathrm{Cp}_{3} \mathrm{Ln}(\mathrm{Ln}=$ lanthanides) were not successful. We observed no reactions at lower temperature and decomposition products at higher temperatures.

b) Organometallic hydroxides of Group 14

We were especially interested in the preparation of hydroxides with low valent Group 14 elements. The reaction of $\mathrm{LGeCl}\left(\mathrm{L}=\mathrm{HC}(\mathrm{CMeNAr})_{2}, \mathrm{Ar}=2,6\right.$ $\left.{ }_{1} \mathrm{Pr}_{2} \mathrm{C}_{6} \mathrm{H}_{3}\right)$ with water in the presence of 1,3-diisopropyl-4,5-dimethylimidazol-2ylidene $(: C)$ resulted in the formation of $\mathrm{LGeOH}(9)[10]$ (Scheme 4).

$$
\mathrm{LGeCl} \underset{-[\mathrm{H}: \mathrm{C}]^{+} \mathrm{Cl}^{-}}{\stackrel{: \mathrm{C}, \mathrm{H}_{2} \mathrm{O}}{\longrightarrow}} \mathrm{LGeOH}
$$

\section{9}

Scheme 4: Preparation of $\mathrm{LGeOH}$ (9)

The coordination geometry of 9 around the germanium center is distorted tetrahedral. The germanium atom in 9 is attached to two nitrogen atoms of the ligand $L$ and one hydroxyl group. The fourth coordination site is occupied by a lone pair of electrons. The latter assumption is supported by the presence of intermolecular interaction as evident from the short $\mathrm{OH} \cdots \cdot \mathrm{Ge}$ distance of $3.064 \AA$ between the hydrogen of the hydroxyl group and the germanium atom of an adjacent molecule leading to the existence of 9 as a dimer. The LGeOH does not rearrange to the corresponding structure of composition $L G e=O(H)$ [10]. This is quite in contrast to $\mathrm{RC}(\mathrm{OH})$ which turned out to be very unstable.

More recently we found that the reaction of LGeH with nitrous oxide $\left(\mathrm{N}_{2} \mathrm{O}\right)$ proceeds under the formation of $\mathrm{LGeOH}$ (9) in almost quantitative yield under insertion of the oxygen into the Ge-H bond (Scheme 5) [11].

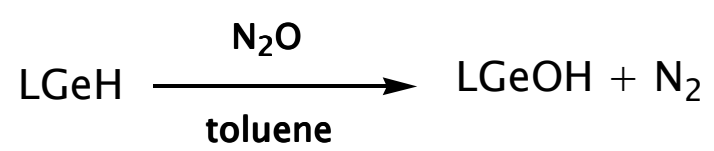

Scheme 5: Alternative preparation of $\mathrm{LGeOH}(9)$

This alternative route to 9 does not need the $\mathrm{N}$-heterocyclic carbene which was used for the preparation of 9 when starting from $\mathrm{LGeCl}$. 
Finally we were able to show that the following sequence of reactions also leads to LGeOH (9) (Scheme 6) [12].

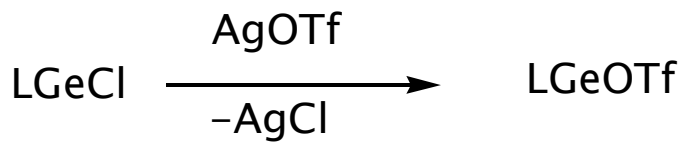

$$
\begin{aligned}
& \text { LGeOTf }+: \mathrm{C}^{1} \longrightarrow \\
& \mathrm{Ar}=2,6-\mathrm{Pr}_{2} \mathrm{C}_{6} \mathrm{H}_{3} \\
& \mathrm{Tf}=\mathrm{CF}_{3} \mathrm{SO}_{3}{ }^{-} \quad \mathrm{L}-\mathrm{H}=\mathrm{L}^{1} \\
& : C^{1}=1,3 \text {-di-tert-butylimidazol-2-ylidene } \\
& \mathrm{L}^{1} \mathrm{Ge}+\mathrm{H}_{2} \mathrm{O} \longrightarrow \mathrm{LGeOH} \\
& \begin{array}{ll}
10 & 9
\end{array}
\end{aligned}
$$

Scheme 6: Preparation of 9 using germylene 10

The easy access to $\mathrm{LGeOH}$ motivated us to prepare analogously the tin compound $\mathrm{LSnOH}$ from $\mathrm{LSnCl}$ and water in the presence of $\mathrm{N}$-heterocyclic carbene. However, this route was not possible.

The precursor we used was $\mathrm{LSnNMe}_{2}$ (11) which was prepared from $\mathrm{LSnCl}$ and $\mathrm{LiNMe}_{2}$. Compound 11 easily reacts with $\mathrm{Fe}_{2}(\mathrm{CO})_{9}$ to from the adduct $\mathrm{LSnNMe}_{2}\left(\mathrm{Fe}(\mathrm{CO})_{4}\right)$ (12) under elimination of $\mathrm{Fe}(\mathrm{CO})_{5}$. The latter reacts with water under elimination of $\mathrm{HNMe}_{2}$ (Scheme 7) and formation of the target molecule 13 [13]. 
<smiles>COC(=O)[SnH](C)N(C)C</smiles>

12<smiles>CC(=O)[C@H](O)[SnH2]O</smiles>

13

Scheme 7: Preparation of the first well-characterized stannylenehydroxide complex 13

c) Organometallic hydroxides of Group 2

A hydrocarbon soluble substituted calcium hydroxide of composition $\left[\mathrm{LCa}(\mathrm{OH}) \cdot \mathrm{THF}_{2}(14)\right.$ was prepared from $\mathrm{LCaN}\left(\mathrm{SiMe}_{3}\right)_{2} \cdot \mathrm{THF}$ and water (Scheme 8).

$$
\begin{aligned}
& 2 \mathrm{LCaN}\left(\mathrm{SiMe}_{3}\right)_{2} \cdot \mathrm{THF}+2 \mathrm{H}_{2} \mathrm{O} \rightarrow[\mathrm{LCa}(\mathrm{OH}) \cdot \mathrm{THF}]_{2}+2 \mathrm{HN}\left(\mathrm{SiMe}_{3}\right)_{2} \\
& 14 \\
& \mathrm{~L}=\mathrm{HC}(\mathrm{CMeNAr})_{2}, \mathrm{Ar}=2,6-\mathrm{Pr}_{2} \mathrm{C}_{6} \mathrm{H}_{3}
\end{aligned}
$$

Scheme 8: Preparation of hydrocarbon-soluble calcium hydroxide

Compound 14 is remarkably stable against ligand exchange and formation of $\mathrm{Ca}(\mathrm{OH})_{2}[14]$.

Controlled hydrolysis of $\mathrm{LSrN}\left(\mathrm{SiMe}_{3}\right)_{2} \cdot \mathrm{THF}$ leads to the hydrocarbon-soluble strontium hydroxide $\mathrm{LSr}(\mathrm{THF})(\mu-\mathrm{OH})_{2} \mathrm{Sr}(\mathrm{THF})_{2} \mathrm{~L}$ (15). From the two strontium atoms of 15 one is coordinate to a single THF while the other one is coordinate to two THF molecules [15].

d) Organometallic hydroxides of Group 4

The controlled hydrolysis of $\mathrm{Cp}^{*}{ }_{2} \mathrm{ZrMe}_{2}$ with one equivalent of water at $-30{ }^{\circ} \mathrm{C}$ resulted in the formation of $\mathrm{Cp}_{2}{ }_{2} \mathrm{ZrMe}(\mathrm{OH})(16)$ in high yield with elimination of methane (Scheme 9). 


$$
\mathrm{Cp}_{2}{ }_{2} \mathrm{ZrMe}_{2}+\mathrm{H}_{2} \mathrm{O} \rightarrow \mathrm{Cp}_{2}{ }_{2} \mathrm{ZrMe}(\mathrm{OH})+\mathrm{CH}_{4}
$$

16

$$
\mathrm{Cp} *=\mathrm{C}_{5} \mathrm{Me}_{5}
$$

Scheme 9: Preparation of $\mathrm{Cp}_{2}{ }_{2} \mathrm{ZrMe}(\mathrm{OH})$ (16)

Compound 16 is a crystalline compound and was characterized by single crystal X-ray structural analysis [16]. Compound 16 is soluble in $n$-hexane, toluene, ether, tetrahydrofuran, and dichloromethane. The corresponding $\mathrm{Cp}^{*}{ }_{2} \mathrm{HfCl}(\mathrm{OH})(17)$ was only prepared in situ using $\mathrm{Cp}^{*}{ }_{2} \mathrm{HfCl}_{2}$ and equivalent amounts of water [17].

$$
\mathrm{Cp}_{2}{ }_{2} \mathrm{HfCl}_{2}+\mathrm{H}_{2} \mathrm{O} \rightarrow \mathrm{Cp}_{2}{ }_{2} \mathrm{HfCl}(\mathrm{OH})+\mathrm{HCl}
$$

Scheme 10: Synthesis of $\mathrm{Cp}_{2}{ }_{2} \mathrm{HfCl}(\mathrm{OH})$ (17)

\section{Assembling of Heterobimetallic Oxides}

A few organometallic hydroxides of Group 13 and 14 turned out to be useful precursors for the preparation of oxyen bridged Main Group f-element systems. The majority of the prepared hydroxides did not react at room temperature and decomposed at elevated temperatures. However, reaction of $\operatorname{LAIMe}(\mathrm{OH})$ (1) with a series of $\mathrm{Cp}_{3} \mathrm{Ln}$ ( $\mathrm{Ln}=$ lanthanide) showed selective reactivity and complexes of composition LAIMe $(\mu-\mathrm{OH}) \operatorname{LnCp}_{3} \quad[\mathrm{Ln}=\mathrm{Sm} 18$, Dy 19, $\operatorname{Er} 20]$, LAIMe( $\left.\mu-O\right) \operatorname{LnCp}(\mathrm{THF})$ $[\mathrm{Ln}=\mathrm{Yb} 21$, Dy 22, $\operatorname{Er} 23]$ and $\operatorname{LAIMe}(\mu-\mathrm{O}) \mathrm{YbCp}_{2} 24$ were obtained in good yield (Scheme 11) [18]. 


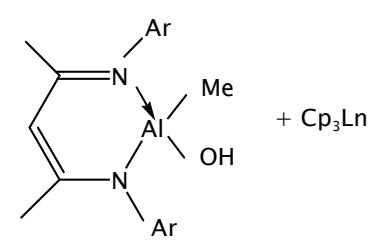

1, $\mathrm{Ar}=2,6-\mathrm{Pr}_{2} \mathrm{C}_{6} \mathrm{H}_{3}$ $\mathrm{Cp}=\mathrm{C}_{5} \mathrm{H}_{5}$

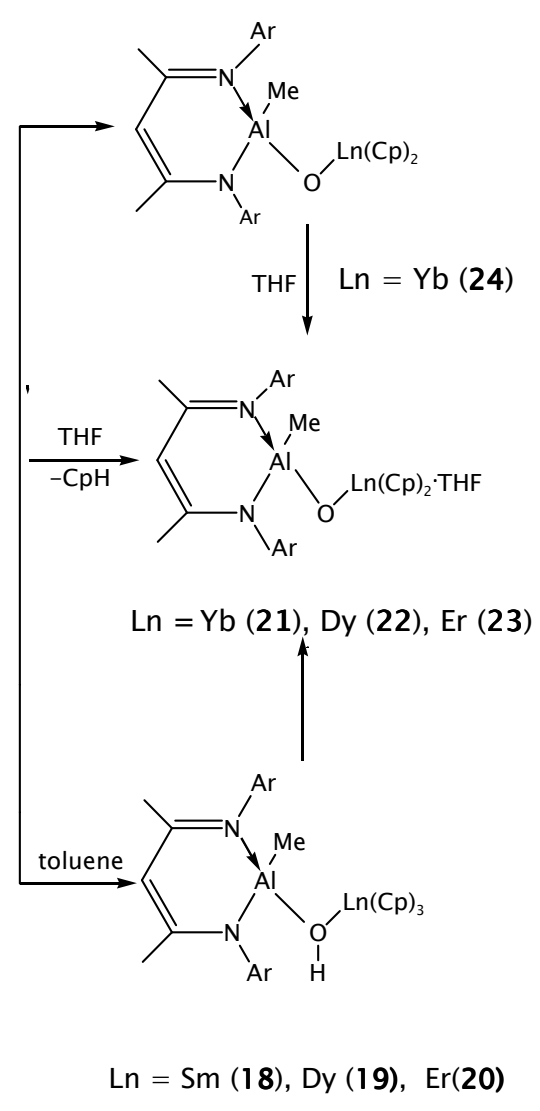

Scheme 11: Preparation of Al-O-Ln compounds

The formation of the $\mathrm{Al}-\mathrm{O}-\mathrm{Ln}$ unit is a multi step process. First the adduct $\operatorname{LAIMe}(\mu-\mathrm{OH}) \mathrm{LnCp}_{3}$ is formed which at elevated temperatures eliminates $\mathrm{CpH}$ to generate the Al-O-Ln moiety (Scheme 11) [18]. The compounds have been characterized by single crystal X-ray structural analysis.

$\mathrm{LGaMe}(\mathrm{OH})$ (2) was prepared by the same method like that for $\mathrm{LAIMe}(\mathrm{OH})$ (1) using $\mathrm{LGaMeCl}$ and water in the presence of a $\mathrm{N}$-heterocyclic carbene [8]. The reaction of 2 with $\mathrm{Cp}_{3} \mathrm{Ln}$ leads to the products $\operatorname{LGaMe}(\mu-\mathrm{OH}) \operatorname{LnCp_{3}}[\mathrm{Ln}=\mathrm{Sm} 25, \mathrm{Nd}$ 26, Yb 27] (Scheme 12) [19]. 


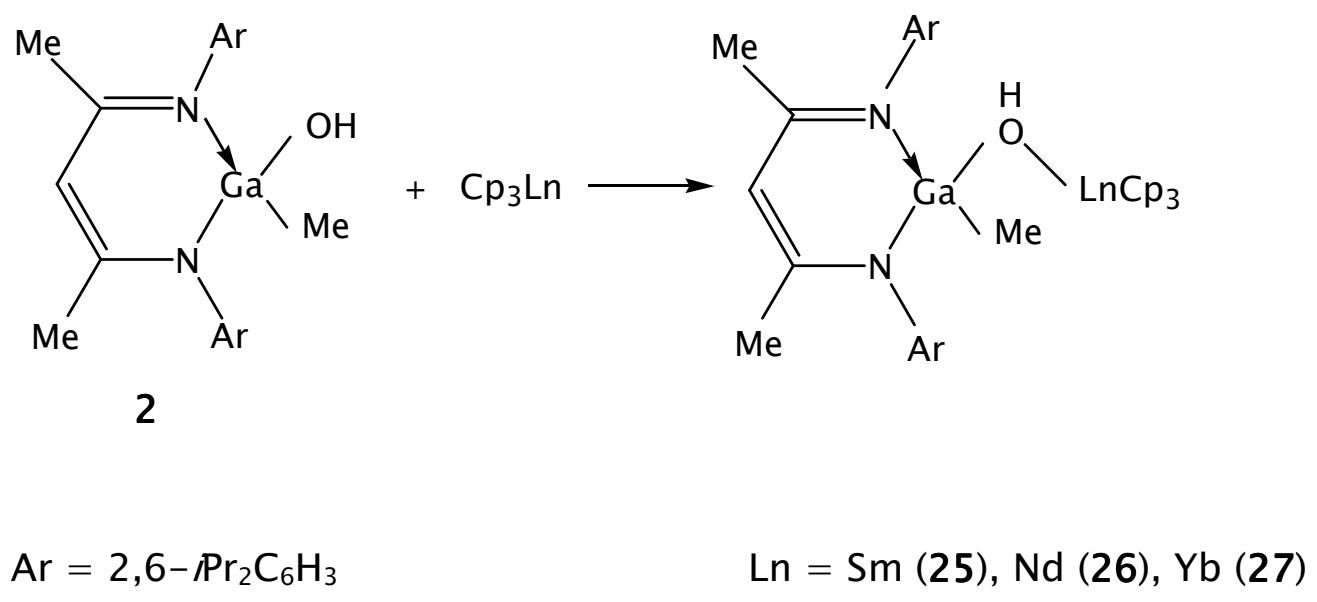

Scheme 12: Synthesis of compounds with the $\mathrm{Ga}-(\mathrm{OH})-\mathrm{Ln}$ skeleton

The less acidic nature of 2 in comparison to that of 1 does not lead to products under elimination of $\mathrm{CpH}$. Compounds 25 and 26 have been characterized by single crystal X-ray structures [19].

Another successful example is the preparation of the monomeric heterobimetallic oxide of composition $\mathrm{LGe}-\mathrm{O}-\mathrm{Cp}_{2} \mathrm{Ln} \cdot \mathrm{THF}$ with a $\mathrm{Ge}(\mathrm{II})-\mathrm{O}-\mathrm{Ln}$ skeleton. The synthesized compounds of composition $\mathrm{LGe}(\mu-\mathrm{O}) \mathrm{LnCp} \mathrm{p}_{2} \cdot \mathrm{THF}(\mathrm{Ln}=\mathrm{Yb}$ 28, Y 29) are shown in Scheme 13 [20].
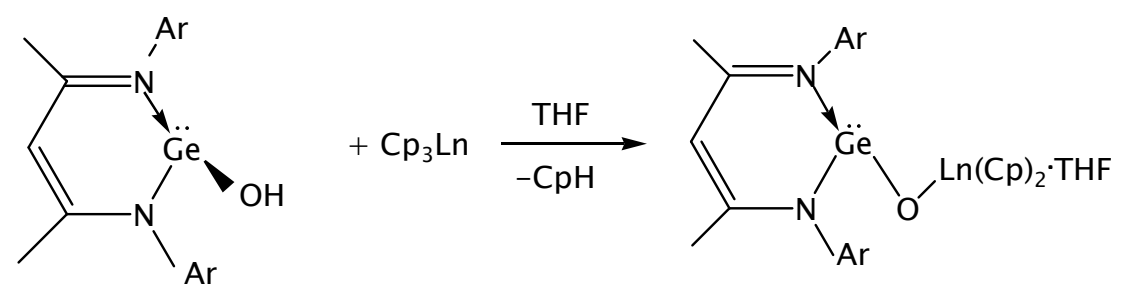

$\mathrm{Ar}=2,6-\mathrm{Pr}_{2} \mathrm{C}_{6} \mathrm{H}_{3}$

$\operatorname{Ln}=\mathrm{Yb}(28), \mathrm{Y}(29)$

Scheme 13: Germanium(II) oxides of ytterbium and yttrium

Compounds 28 and 29 have been characterized by single crystal structural analysis. Presently these are the only examples containing the $\mathrm{Ge}(\mathrm{II})-\mathrm{O}-\mathrm{Ln}$ linkage reported in literature. The $\mathrm{N}-\mathrm{Ge}-\mathrm{N}$ bond angles of 28 and 29 are found to be less than $90^{\circ}$ which may be attributed to the stereochemically active lone pair of 
electrons on the germanium demanding higher angular volume for its accommodation [20].

\section{Application of Heterobimetallic Oxides}

Compounds of composition $\operatorname{LAIMe}(\mu-\mathrm{O}) \mathrm{ZrRCp}_{2}$ where $\mathrm{R}$ is $\mathrm{CH}_{3}$ or chlorine exhibit the highest activity in ethylene polymerization. The activity was observed (activity $=\mathrm{g}$ polyethylene $/ \mathrm{mol} \cdot$ cat $\cdot \mathrm{h}$ ) in the order of $10^{6}$ [7]. According to DFT calculation the bridging oxygen lowers the electron density at the metal centers of these complexes with the consequence that they increase their electrophilicity. This results in a remarkable decrease in the amount of the cocatalyst and increase in activity. The polymerization experiments with ethylene were carried out with a variety of different $\mathrm{M}-\mathrm{O}-\mathrm{M}$ ' systems such as LAIMe $(\mu-\mathrm{O}) \operatorname{TiMe}_{2} \mathrm{Cp}$ [21], LAIMe( $\mu$ O) $\mathrm{HfMeCp}_{2}$ [22], Cp* ${ }_{2} \mathrm{ZrMe}(\mu-\mathrm{O}) \mathrm{TiMe}_{2} \mathrm{Cp}^{*}$ [23].

The ring opening polymerization of $\epsilon$-caprolactone was realized with some of the lanthanide complexes 18 - 24 given in Scheme 11. These complexes exhibit catalyst activity with almost quantitative yield and polydispersities $\left(M_{w} / M_{n}\right)$ in the order of 1.5 to 2.3 at ambient temperature in THF or toluene (see Table 1).

Table 1: Polymerization of $\epsilon$-caprolactonea

\begin{tabular}{|c|c|c|c|c|c|c|}
\hline Compound & Solvent $T$ & $\mathrm{~T}\left({ }^{\circ} \mathrm{C}\right)$ & Time $(\mathrm{h})$ & Yield (\%) & $M_{n}$ & $\mathrm{M}_{\mathrm{w}} / \mathrm{M}_{\mathrm{n}}$ \\
\hline LAIMe $(\mu-\mathrm{O}) \mathrm{YbCp}_{2}$ (THF) (21) & THF & 22 & 3 & 96 & 51766 & 1.6 \\
\hline LAIMe $(\mu-O) Y_{b C p_{2}}(\mathrm{THF})(21)$ & toluene & e 70 & 0.5 & 95 & 18556 & 2.3 \\
\hline LAIMe $(\mu-O) Y b C p_{2}(T H F)(21)$ & THF & 70 & 0.5 & 96 & 24172 & 2.1 \\
\hline $\operatorname{LAIMe}(\mu-\mathrm{O}) \mathrm{DyCp}_{2}(\mathrm{THF})(22)$ & THF & 22 & 3 & 95 & 61345 & 1.7 \\
\hline $\operatorname{LAIMe}(\mu-\mathrm{O}) \mathrm{DyCp}_{2}$ (THF) (22) & THF & 70 & 0.5 & 96 & 33256 & 1.7 \\
\hline $\operatorname{LAIMe}(\mu-0) \mathrm{YbCp}_{2}(24)$ & toluene & le 22 & 5 & 94 & 21807 & 1.5 \\
\hline $\operatorname{LAIMe}(\mu-\mathrm{O}) \mathrm{YbCp}_{2}(24)$ & toluene & ie 70 & 0.5 & 95 & 17718 & 1.8 \\
\hline LAIMe( $\mu-\mathrm{OH}) \mathrm{DyCp}_{3}$ (19) & toluene & 22 & 5 & 95 & 20934 & 1.6 \\
\hline $\operatorname{LAIMe}(\mu-\mathrm{OH}) \mathrm{DyCp}_{3}(19)$ & toluene & e 70 & 0.5 & 97 & 39690 & 1.7 \\
\hline
\end{tabular}




\section{Unforeseen Result in Lanthanide Chemistry}

To our surprise the preparation of $\left[\left(\mathrm{Me}_{3} \mathrm{Si}\right)_{2} \mathrm{NC}(\mathrm{NCy})_{2} \mathrm{SmCl}_{2}\right]_{5}(\mathrm{THF})_{2}$ (25) from anhydrous $\mathrm{SmCl}_{3}$ and $\left(\mathrm{Me}_{3} \mathrm{Si}\right)_{2} \mathrm{NC}(\mathrm{NCy})_{2} \mathrm{Li}$ in a mixture of THF and toluene resulted in the chlorine-centered cluster (Scheme 14) [24]. The cluster crystallizes in the triclinic space group $P-1$. The single crystal X-ray structure confirmed that no Li ions are incorporated in the cluster. This is a unique assembly of substituted samarium chlorides.

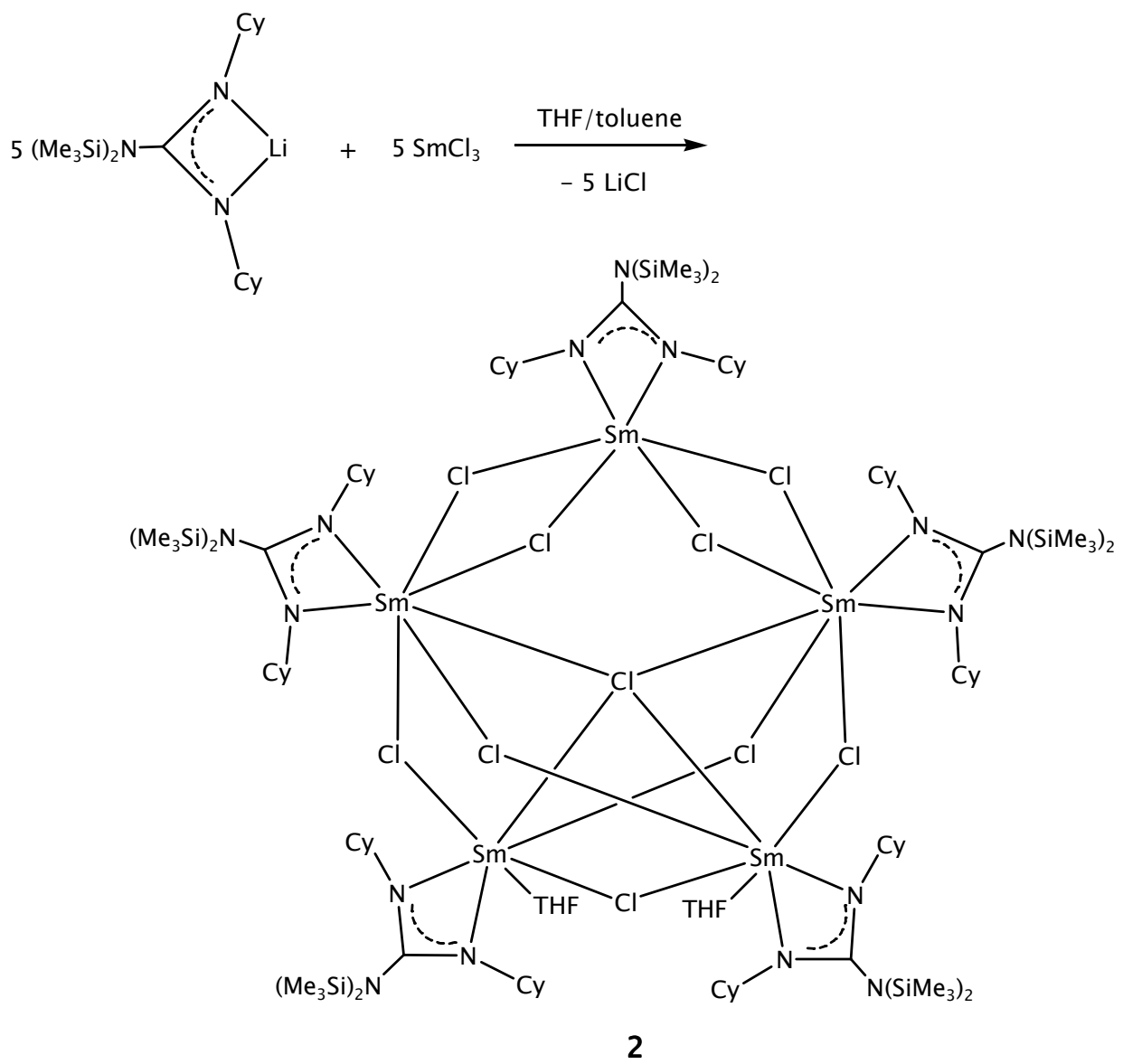

Scheme 14: Preparation of $\left[\left(\mathrm{Me}_{3} \mathrm{Si}\right)_{2} \mathrm{NC}(\mathrm{NCy})_{2} \mathrm{SmCl}_{2}\right]_{5}(25 \cdot 2 \mathrm{THF})$

The molecular structure of the cluster is shown in Figure 2. The Cy groups on the nitrogen atoms are omitted for clarity. 


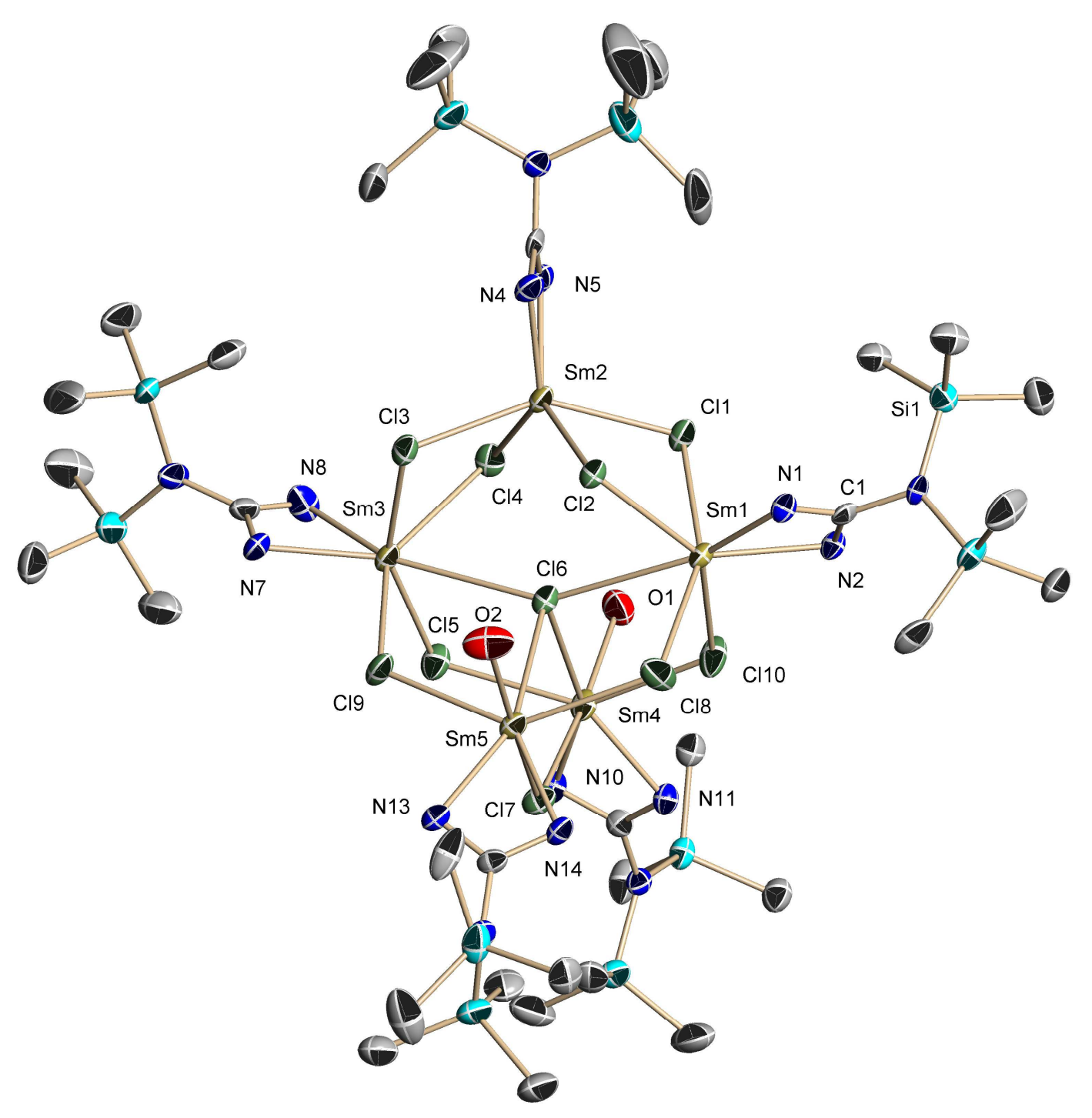

Figure 2: Molecular structure of $\left[\left(\mathrm{Me}_{3} \mathrm{Si}\right)_{2} \mathrm{NC}(\mathrm{NCy})_{2} \mathrm{SmCl}_{2}\right]_{5}(\mathrm{THF})_{2}(25 \cdot 2 \mathrm{THF})$

In contrast to the reaction with $\mathrm{SmCl}_{3}$ the analogues reaction with $\mathrm{YbCl}_{3}$ resulted in the expected dimer of composition $\left[\left(\mathrm{Me}_{3} \mathrm{Si}\right)_{2} \mathrm{NC}\left(\mathrm{NCY}_{2}\right)_{2} \mathrm{YbCl}_{2}\right]_{2} \cdot(\mathrm{LiCl})_{2}(\mathrm{THF})_{4}$ with incorporated lithium chloride molecules (Scheme 15). 


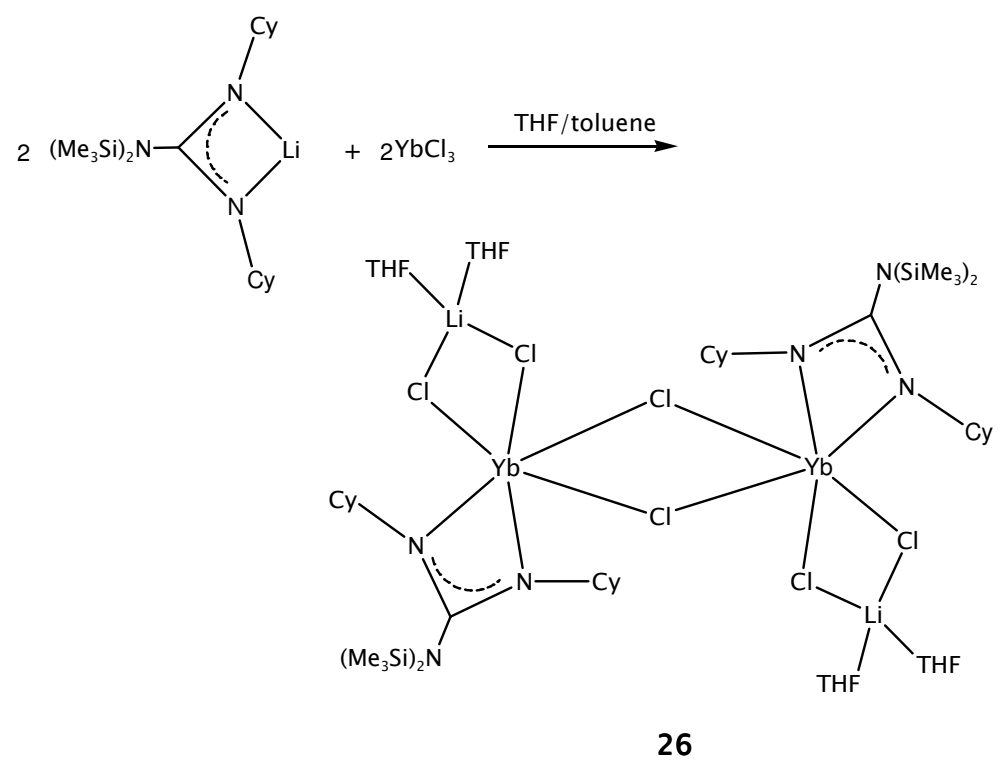

Scheme 15: Synthesis of $\left[\left(\mathrm{Me}_{3} \mathrm{Si}\right)_{2} \mathrm{NC}\left(\mathrm{NCy}_{2}\right)_{2} \mathrm{YbCl}_{2}\right]_{2}$ (26)

\section{Acknowledgment}

The results presented in this report were only possible by support of the Deutsche Forschungsgemeinschaft under the Schwerpunktprogramm (RO 224/51) "Lanthanoidspezifische Funktionen in Molekül und Material". The support is highly acknowledged. Moreover I am thankful to the students and post docs for their excellent work. The names are given in the references.

\section{References}

[1] E. Colacio, J.-P. Costes, J.M. Dominguez-Vera, I.B. Maimoun, J. Suárez-Varela, Chem. Commun. 2005, 534 - 536.

[2] Y.-Z. Zhang, S. Gao, H.-L. Sun, G. Su, Z.-M. Wang, S.-W. Zhang, Chem. Commun. 2004, $1906-1907$.

[3] A. Mishra, W. Wernsdorfer, K.A. Abboud, G. Christou , J. Am. CHem. Soc. 2004, 126, $15648-15649$.

[4] M. Fujiwara, H. Wessel, H.S. Park, H.W. Roesky, Chem. Mater. 2002, 14, 4975 $-4981$.

[5] J.W. Gilje, H.W. Roesky, Chem. Rev. 1994, 94, 895 - 910.

[6] H.W. Roesky, S. Singh, K.K.M. Yusuff, J.A. Maguire, N.S. Hosmane, Chem. Rev. 2006, 106, $3813-3843$.

[7] G. Bai, S. Singh, H.W. Roesky, M. Noltemeyer, H.-G. Schmidt, J. Am. Chem. Soc. 2005, 127, $3449-3455$. 
[8] S. Singh, V. Jancik, H.W. Roesky, R. Herbst-Irmer, Inorg. Chem. 2006, 45, 949 $-951$.

[9] Y. Yang, T. Schulz, M. John, Z. Yang, V.M. Jiménez-Pérez, H.W. Roesky, M. Gurubasavaraj, D. Stalke, H. Ye, Organometallics 2008, 27, 769 - 777.

[10] L.W. Pineda, V. Jancik, H.W. Roesky, D. Neculai, A.M. Neculai, Angew. Chem. Int. Ed. 2004, 43, 1419 - 1421; Angew. Chem. 2004, 116, 1443 - 1445.

[11] A. Jana, H.W. Roesky, C. Schulzke, Dalton Trans. 2010, 39, 132 - 138.

[12] A. Jana, B. Nekoueishahraki, H.W. Roesky, C. Schulzke, Organometallics 2009, $28,3763-3766$.

[13] A. Jana, S.P. Sarish, H.W. Roesky, C. Schulzke, P.P. Samuel, Chem. Commun. 2010, 46, $707-709$.

[14] C. Ruspic, S. Nembenna, A. Hofmeister, J. Magull, S. Harder, H.W. Roesky, J. Am. Chem. Soc. 2006, 128, 15000 - 15004.

[15] S. Sarish, S. Nembenna, S. Nagendran, H.W. Roesky, A. Pal. R. Herbst-Irmer, A. Ringe, J. Magull, Inorg. Chem. 2008, 47, 5971 - 5977.

[16] P. M. Gurubasavaraj, H.W. Roesky, P.M.V. Sharma, R. B. Oswald, V. Dolle, R. Herbst-Irmer, A. Pal, Organometallics 2007, 26, 3346 - 3351.

[17] B. Nekoueishahraki, A. Jana, H.W. Roesky, L. Mishra, D. Stern, D. Stalke, Organometallics, 2009, 28, 5733 - 5738.

[18] J. Chai, V. Jancik, S. Singh, H. Zhu, C. He, H.W. Roesky, H.-G. Schmidt, M. Noltemeyer, N.S. Hosmane, J. Am. Chem. Soc. 2005, 127, 7521 - 7528.

[19] S. Singh, A. Pal, H.W. Roesky, R. Herbst-Irmer, Eur. J. Inorg. Chem. 2006, 4029 - 4032.

[20] Y. Yang, H.W. Roesky, P.G. Jones, C.-W. So, Z. Zhang, R. Herbst-Irmer, H. Ye, Inorg. Chem. 2007, 46, 10860 - 10863.

[21] P.M. Gurubasavaraj, H.W. Roesky, B. Nekoueishahraki, A. Pal, R. Herbst-Irmer, Inorg. Chem. 2008, 47, 5324 - 5331.

[22] P.M. Gurubasavaraj, S.K. Mandal, H.W. Roesky. R.B. Oswald, A. Pal, M. Noltemeyer, Inorg. Chem. 2007, 46, 1056 - 1061.

[23] P.M. Gurubasavaraj, H.W. Roesky, P.M.V. Sharma, R.B. Oswald, D. Dolle, A. Pal, Organometallics 2007, 26, 3346 - 3351.

[24] Z. Zhang, H.W. Roesky, T. Schulz, D. Stalke, A. Döring, Eur. J. Inorg. Chem. 2009, 4864 - 4869. 
